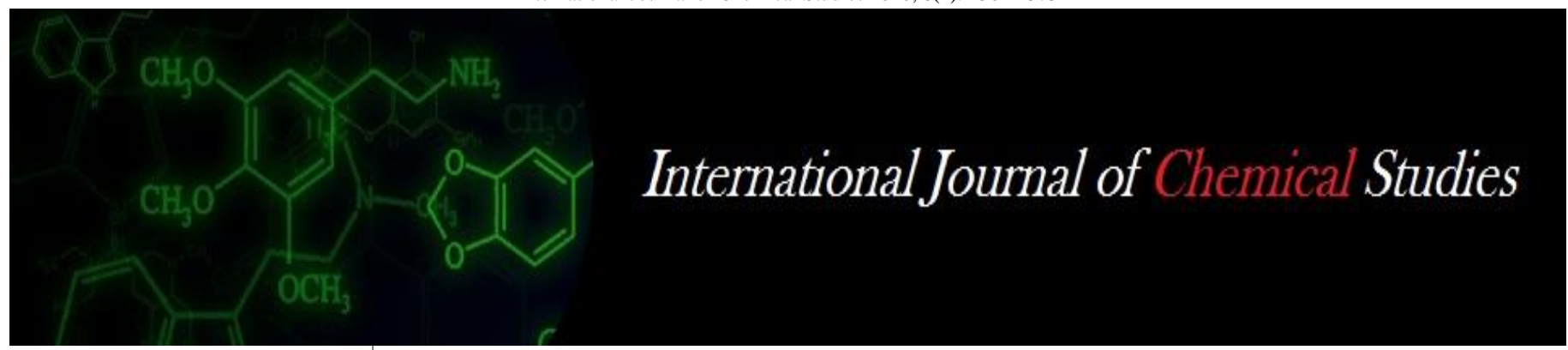

P-ISSN: 2349-8528

E-ISSN: 2321-4902

IJCS 2020; 8(1): 2564-2573

(C) 2020 IJCS

Received: 13-11-2019

Accepted: 15-12-2019

Ankita Choudhary

Division of Food Science and

Technology, SKUAST-J,

Chatha, Jammu and Kashmir, India

\section{Neeraj Gupta}

Division of Food Science and Technology, SKUAST-J,

Chatha, Jammu and Kashmir, India

\section{Fozia Hameed}

Division of Food Science and Technology, SKUAST-J,

Chatha, Jammu and Kashmir, India

\section{Skarma Choton}

Division of Food Science and Technology, SKUAST-J, Chatha, Jammu and Kashmir, India

Corresponding Author: Ankita Choudhary

Division of Food Science and

Technology, SKUAST-J,

Chatha, Jammu and Kashmir,

India

\section{An overview of food adulteration: Concept, sources, impact, challenges and detection}

\author{
Ankita Choudhary, Neeraj Gupta, Fozia Hameed and Skarma Choton
}

DOI: https://doi.org/10.22271/chemi.2020.v8.i1am.8655

\begin{abstract}
Food is any substance composed of carbohydrates, water, fats and proteins, which can be eaten or drunk by humans or animals for nutrition or very important aspect for life. Food products are often a target of adulteration while supply chains usually deal with perishable products that could be harmful to consumers if they are not managed properly. Economic adulteration is a long term problem affecting the food industry. Adulteration in food has been a concern since the beginning of civilization, as it not only decreases the quality of food products but also results in a number of ill effects on health. Food adulteration involves the infusion of useless, harmful, unnecessary substances to food which decreases the quality of food. The problems of adulteration makes the food items used in our daily life unsafe and unhygienic for use due to poor handling. Adulteration in food items can cause tremendous affect on health without our knowledge. If we tend to actively participate in these changes then we can bring about a healthy and non venturous future for the upcoming generations.
\end{abstract}

Keywords: Food adulteration, concept, sources, impact, challenges, detection

\section{Introduction}

Food is one of the basic needs for every living being and is composed of carbohydrates, water, fats and proteins, which can be eaten or drunk by animals, including humans, for nutrition or pleasure (FAO/WHO, 2007) ${ }^{[22]}$. Food commodities have always been vulnerable to fraudulent admixture or adulteration with cheaper inferior materials. In India, food safety is a growing problem with rampant instances of adulteration and contamination of essential foods that can be a potential source of disease infection or toxic poisoning. Food spoilage occurs mostly during handling from the primary producers to the consumers (Gahukar, 2014) ${ }^{[26]}$. The awareness of consumers plays important role in preventing food adulteration. Unawareness and unfair market behaviour might endanger consumer health and misleading can lead to poisoning. Therefore basic screening tests should be known to common people (Vasanthakalaam, 1996) ${ }^{[67]}$. In September 1998, the Canadian government warned its citizens not to consume any foodstuff cooked or processed in oil from India as it could be adulterated with argemone. Scores had died or were crippled in north India as unscrupulous traders mixed the fatal argemone oil to mustard oil to raise their profits. Human lives have such low value in India that it just passed off as another tragedy.

Milk is being adulterated with synthetic chemicals and detergent powder that could cause irreparable damage. It is another flourishing business. In the trade, it is known as synthetic milk. The Delhi police in May 2000 seized 76,000 litres of adulterated milk packed in pouches similar to the ones of Mother Dairy run by the prestigious National Dairy Development Board. Elsewhere, in places like Bangalore, fat is being removed from milk and then sold after mixing it with harmful chemicals to whiten and thicken the thin liquid. When you move about in the market and see the attractively decorated sweets and other edible items your appetite becomes almost insatiable. And that's what it is meant to do to you. Attract you to buy and eat. But wait! In the process you may be eating "Metanil yellow" a non-permitted coal tar dye commonly known as 'Kishori Rang', "Rhodamin-B", "Lead Chromate" or perhaps "Ultra Marine Blue". These are all non-permissible and banned colours and they cause serious health hazards and may also cause cancer in the long run. They are carcinogenic. We may be eating a dangerous dye, sawdust, soap stone, industrial starch, Aluminum foil and believe it, even cowdung! Invite disease rather than good health (Ghosh, 2012). 
Food adulteration is a process in which the quality of food is lowered or reduced by replacing food ingredient or addition of non authenticated substances or removal of a vital component from food for the sake of earning profit or due to other incidental reasons. Food adulteration ultimately deceives consumers and leads various health risks. Nowadays, it is very difficult to find a sector of food industry which is free of adulteration. Because of that it is important for the consumer to know the common adulterants and their effect on health since the increasing number of food producers and the outstanding amount of foodstuffs import enables the producers to mislead and cheat consumers. An adulterants are chemical substances which should not be contained within our food or beverage, and may be intentionally added to more expensive substances to increase visible quantities and reduce manufacturing costs, or for some other deceptive or malicious purpose (Anita and Neetu, 2013) ${ }^{[4]}$. As the usage of adulterants has increased tremendously in recent years, there has been a growing interest among consumers in the safety and traceability of food products.

Prevention of Food Adulteration Act, 1954, an Act that defined food safety norms in the country, defined that a food article is considered adulterated, if

a. The article sold by a vendor is not of the nature, substance or quality demanded by the purchaser or which it purports to be;

b. The article contains any substance affecting its quality or of it is so processed as to injuriously affect its nature, substance or quality;

c. Any inferior or cheaper substance has been substituted wholly or partly for the article, or any constituent of the article has been wholly or partly abstracted from it, so as to affecting its quality or of it is so processed as to injuriously affect its nature, substance or quality;

d. The article had been prepared, packed or kept under insanitary conditions whereby it has become contaminated or injurious to health;

e. The article consists wholly or in part of any filthy, putrid, disgusting, rotten, decomposed or diseased animal or vegetable substance or being insect infested, or is otherwise unfit for human consumption;

f. The article is obtained from a diseased animal;

g. The article contains any poisonous or other ingredient, which is injurious to health;

h. The container of the article is composed of any poisonous or deleterious substance, which renders its contents injurious to health;

i. The article contains any prohibited colouring matter or preservative, or any permitted colouring matter or preservative in excess of the prescribed limits;

j. The quality or purity of the article falls below the prescribed standard, or its constituents are present in proportions other standard, or its constituents are present in proportions other than those prescribed, whether or not rendering it injurious to health.

\section{History}

Adulteration use was first investigated in 1820 by the German chemist Frederick Accum, who identified many toxic metal colonings in ford and drink. His work antagonized food suppliers and he was ultimately discredited by a scandal over his alleged mutilation of book "The royal institution library. The physician author Hill Hossal conducted extensive studies in the early 1850 which were published in the lancet and led to the 1860 food Adulteration Act and rather legislation (Ghimire, 2016).

\section{Why food adulteration?}

Adulteration is present in society from a long time but it was not noticed due to its small scale use and its low impact. But at the present era, economic adulteration is a long term problem affecting the food industry at its most drastic level. According to one survey conducted, adulteration were detected in milk to the tune of $70 \%$ with water, turmeric powder- $43 \%$ with chalk powder, red chilli powder- $100 \%$ with artificial colour, sugar 37\% with chalk powder etc. (Kumar, 2011). As Afzal et al. (2011) ${ }^{[2]}$ the main reason that attracts adulteration is for boosting their cash income by increasing its volume. Even though increasing their profit margins initiated adulteration done by some selfish producers, processors and retailers, the main cause for adulteration is dishonesty and lack of accidental quality assessment on products suspected (Asrat and Zelalem, 2014) ${ }^{[5]}$. As world population is growing at alarming rate, food is often adulterated to meet the needs of this growing population and to feed the large scale population. Another motive for faking and adulteration of goods and services is outsourcing to offshore producers (Hamburg, 2010) [29]. Outsourcing became possible because comparatively labour is cheap in some countries and this is also what makes product faking easy since the cost of producing is far less compared to the super normal profits being made (Sicpa, 2012) [62]. That is why Cofie (2012) ${ }^{[11]}$ argues that counterfeiting thrives on the whole process of globalization because spread of capital and know-how to new markets is usually achieved through globalization. Ehsan et al. (2010) ${ }^{[18]}$ reported that people were enthused by the high price of fuel to adulterate fuel in Bangladesh in order to gain undue financial benefits. According to Narayan (2014) [49] generally foods and drinks are adulterated for the following six reasons. These are:-

1. When the demand is more than the supply in the market,

2. To come at par with the market competitors by lowering the cost of production,

3. The greed for increased profit margins,

4. The common man cannot afford food items with their original constituents,

5. Lack of trained manpower with outdated food processing techniques and

6. No idea about the disease outbreaks caused due to adulterated food products.

\section{Types of adulteration}

Adulteration of foods is done by many means but broadly there are two types of adulterantions. According to El-loly et al. (2013) ${ }^{[19]}$ there are intentional/deliberately/knowingly and unintentional/unknowingly/incidental adulterations.

\section{Intentional adulteration}

Intentional adulteration is an adulteration in which food item is deliberately adulterated. It is inclusion of inferior substances having properties similar to the foods in which they are added. They are thus difficult to detect. The adulterant could be physical or biological in nature. It is done in order to promote the level of their essential nutrients after reduction of a given amount in order to increase their profit margin by several chemicals like urea, melamine, and increase its volume by adding substances such as starch, flour, cane sugar, vegetable oils, water, skim milk, sand, chalk powder, molasses, stone, brick powder, ergot, chicory, roasted 
barley powder, grinded papaya seeds, etc. into various food items (El-loly et al., 2013) ${ }^{[19]}$. It is the most dangerous form of adulteration because of amounts of nutrients deducted and extraneous substances added into food items that is done by business oriented people just forgot the humanity in behind of money making mentality (Awasthi et al., 2014) ${ }^{[8]}$.

According to Lakshmi et al. (2012) ${ }^{[38]}$, Olive oil, milk, honey, saffron, orange juice, coffee and apple juice are the seven most likely food ingredients to be targets for intentional or economically motivated adulteration of food, or food fraud, according to analysis of the first U.S. public database created to compile information on risk factors for food fraud published in the Journal of Food Science.

\section{Incidental adulteration}

Adulteration which is due to lack of proper hygienic conditions of food products and drinks throughout production site to consumption table. Accidental adulterants are pesticides residues, dropping of rodents, larvae in foods, etc. Metallic contamination with arsenic lead, mercury can also occur accidentally. Accidental adulterants also involve pests such as rodents and insects that trespasses the food at high degree and produces impurity in the form of excreta, bodily secretions and spoilage through micro-organisms. Most common accidental adulterants are pesticides, D.D.T. and residues present on the plant product (Pandit et al., 2002) ${ }^{[53]}$. Maximum permissible limit for D.D.T. is $3 \mathrm{ppm}$ which sometimes is over crossed (Kannan et al., 1997) ${ }^{[33]}$.

\section{Various food items and their adulterants}

Almost every food-item from milk to fruits, from vegetables to grains is adulterated at some level. Some adulterants enter via agricultural steps, as they are not cleaned well. These are visible adulterants like stones, leaves, soil, sand and dust to name a few. The consumer can clean them and this makes it less harmful. Other adulterants that are intentionally added are invisible or they are made invisible by astutely camouflaging with the color or texture. They are generally harmful for the health and most of them lead to serious health problems like cancer. Even animal feed like cake as protein supplement for lactating animals is adulterated accounts about 90 percent of un-branded loose forms (Alauddin, 2012) ${ }^{[3]}$.

Table 1: Different food items and their adulterants

\begin{tabular}{|c|c|c|c|}
\hline Food \& drink items & Adulterant/extraneous substances & Purpose & Type of adulteration \\
\hline Ghee & Vanaspati, anatta, \& oleomargarine & To make more yellow & Deliberate \\
\hline Milk & Water, skim milk & To increase volume & Deliberate \\
\hline Condensed milk & Paneer, khoya & To give rich textur & Deliberate \\
\hline Butter & Vegetable oil, anatta, banana, oleomargarine & To increase volume \& make yellowish & Deliberate \\
\hline Ice cream & Starch, rice powder or wheat flour & To thicken cream & Deliberate \\
\hline Tea leaves & Black/Bengal gram dal husk with color & To add color & Deliberate \\
\hline Red wine & Juice of bilberries & $\begin{array}{c}\text { To attract/produce deep blue precipitate } \\
\text { with lead acetate }\end{array}$ & Deliberate \\
\hline Mustard oil & Papaya seed & To add bulk and weight & Deliberate \\
\hline Black pepper & Papaya seed & To add bulk & Deliberate \\
\hline Green chillies\& peas & Malachite green & To give bright glowing green color & Deliberate \\
\hline Chillies powder & Brick powder & To increase weight & Deliberate \\
\hline Sugar & Chalk powder & To increase amount & Deliberate \\
\hline Oils & Rancid oil & To increase volume & Deliberate \\
\hline Coriander powder & Cow dung powder & To increase amount & Deliberate \\
\hline Pulses & Lathyrus sativus & To increase weight & Deliberate \\
\hline Common salt & White powdered stone,chalk & To increase amount & Deliberate \\
\hline Coffee & $\begin{array}{c}\text { Chicory, roasted barley powder, tamarind } \\
\text { seeds }\end{array}$ & To add bulk and color & Deliberate \\
\hline Honey & Molasses, cane sugar & To increase volume & Deliberate \\
\hline Wheat & Ergot (poisonous fungus) & To increase weight & Deliberate \\
\hline Jaggery powder & Chalk powder & To increase amount & Deliberate \\
\hline Others like preservatives, etc. & Formalin, etc. & To increases shelf life & Unintentional \\
\hline
\end{tabular}

Depending on the types of foods and drinks adulterated it is possible to see adulteration in four major categories like milk and milk products, fats and oils, food grains and others (animal and plant originated foods) adulteration respectively.

\section{Milk \& milk products adulteration}

In developing countries, the industrialization brought a series of problems along with the much appreciated progress, with the mass collection and distribution of milk from various sources playing the role of potential vehicle for disease transmission. In olden days, milk was collected from small groups of animals in farms and it was supplied to a small number of people living nearby (Chanda et al., 2012) ${ }^{[10]}$. But with the advent of industrialization, population growth and urbanization, the demand increased drastically. Milk supply through the small farms no longer met the increasing demand (Dehinenet et al., 2013) ${ }^{[13]}$. Hence commercialization of the milk industry ultimately took place (Revathi et al., 2012) ${ }^{[59]}$.
Milk adulteration involves adding water to milk and removing the beneficial fats from milk. Often soya milk (ESA, 2012) [20], starch, groundnut milk, and wheat flour are added to milk and girl ghee added into butter. The producers deliberately adulterate milk and its products in order to promote the level of these essential nutrients after reduction of a given amount and/or to mislead the consumers to increase their profit margin by several chemicals like urea, starch, flour, cane sugar, vegetable oils, detergents etc (table 1) (Faraz et al., 2013) ${ }^{[23]}$. Various preservatives like formalin and some antibiotics are also added in milk to increase its shelf life (Awan et al., 2014) ${ }^{[7]}$. This addition decreases the nutritive value of milk (El-loly et al., 2013) ${ }^{[19]}$ and its incidences are at increase over the years according to Alauddin (2012) ${ }^{[3]}$.

Although milk is produced throughout the year yet the supply and demand of milk are related to the seasonal fluctuations (Afzal et al., 2011) ${ }^{[2]}$ due to this milk used by the people for consumption is adulterated to such an extent that there is very 
less nutritive value in it and may also be toxic for public health their profit margin by three ways dilution, extraction of valuable components like milk fat which is removed as cream, addition of cheap substances like starch to increase the value of total solids up to a level which is acceptable by the consumers (El-loly et al., 2013) ${ }^{[19]}$. And all dairy foods are made from milk, and their components are the same as those of milk, except butter being comprised mainly of milk fat, but in varying amounts (Faraz et al., 2013) ${ }^{[23]}$ are also adulterated in one or another forms (Khan et al., 2008) ${ }^{[34]}$. Milk and its products can be exposed for adulteration at different points such as at farm and procurement level, while transporting and processing, in view of the fact that fresh milk is pure when it comes out of the udder and free of adulterants and microbes but can be contaminated by bacteria, yeast, fungi and dust, water, different chemicals or adulterants and animal hair due to livestock keepers' unhygienic milking, handling and storage practices, some dishonest producers retailers and manufacturers (Singuluri and Sukumaran, 2014) ${ }^{[63]}$.

\section{Adulteration of Fats and Oils}

It is easy to adulterate oils and fats. Majority of fats, oils and butter are paraffin wax, castor oil and hydrocarbons. But it is difficult to detect such adulteration. Ghee is often mixed with hydrogenated oils and animal fats. Synthetic colors and flavors are added to other fats to make them appear like ghee.

\section{Food Grain Adulteration}

Food grain adulteration involves mixing sand or crushed stones to increase the weight of food grains. Cereal grains and pulses are mixed with plastic beads that resemble grains in color and size. Very often, water is also sprayed on grains to increase the weight.

\section{Other Adulterations}

Others (animal and plant originated foods) adulteration is common, for example, red chilli powder is often mixed with brick powder, while tea leaves are often mixed with used tea leaves. Pepper is mixed with dried papaya seeds. These adulterations are very harmful to the consumer and they should be addressed by consumer organizations and consumers seriously. Another harmful adulteration is honey adulteration which appeared on the world market in the 1970s when high-fructose corn syrup was introduced by the industry. As the sugars $(60.7$ to $77.8 \%)$ are the major components of honey and the most dominant are the monosaccharides fructose and glucose (accounting for 85 to $95 \%$ ), the actual proportion of glucose to fructose in any particular honey depends largely on the source of the nectar. The average ratio of fructose to glucose is $1.2: 1$. The amount of glucose in honey is usually at a supersaturated level at normal temperatures. With reduction in temperature or water content, the glucose can crystallize out. Saccharose (sucrose) is present in honey at approximately $1 \%$ of its dry weight. Normally, honey contains 12.4 to $24.5 \%$ moisture. Unless the moisture content is below $17 \%$, no fermentation takes place. Consumption of honey and honey products has grown considerably during the last few decades.

However, at the present time, the traceability of this food is limited to the quality of each processor's documentation. In case of doubt or fraud, there is no standardized analysis available that can discriminate or determine the botanical (floral or vegetable) and geographical (regional or territorial) origin of the honey. Counterfeiting and product adulteration are now commonly practiced in the global food marketplace
(Pilizota and Nedic, 2009) ${ }^{[56]}$. Because of its high nutritional value and unique flavor, the price of natural bee honey is relatively much higher than that of other sweeteners. Honey is susceptible to adulteration with cheaper sweeteners; those that have been detected in adulterated honeys include sugar syrups and molasses inverted by acids or enzymes from corn, sugar cane, sugar beet and syrups of natural origin such as maple. Adulteration of pure honey with synthetic honey (based on C4 plant sugars) has become much more prevalent in recent years. In addition, there has been a recent major adulteration problem in honey from the Far East (Pilizota and Nedic, 2009) ${ }^{[56]}$.

\section{Impacts of adulteration}

The problems of adulteration makes the food items used in our daily life unsafe and unhygienic for use due to poor handling (Asrat et al., 2012). In the past few decades, adulteration of food has become one of the serious problems and consumption of adulterated food causes serious diseases like cancer, diarrhoea, asthma, ulcers. In general, adulteration of food items has a very serious impact on producers/farmers, processors or manufacturers/enterprises, consumers and government.

\section{Impacts on enterprises}

Enterprises are impacted by a loss of consumer confidence in their products, recalls and destruction of contaminated products, complaint expenses and increases of insurance premiums and costs related to equipment replacement or cleaning. A supplier's fault is inevitably reported in the mass media, casting doubt on that company's reputation (Pandpal et al., 2012) [54]. This affects not only the sales of that particular product, but also the sales of many other products supplied by the company's warehouse or retailers and even the products can be banned/discarded automatically. The effects of such bans on the food production industry are multiple, profound, and far-reaching. A producer that depends on a banned imported foodstuff not only suffers economic loss to the impacted product but also faces lost sales caused by loss of public confidence. The resulting brand damage can be devastating, and recovery can require significant time and expense when consumers have moved on to other suppliers' products (Ibens, 2014) ${ }^{[32]}$. People have lost their trust in the products. For example, about 40 to $60 \%$ of consumers either ceased or were unwilling to purchase domestic milk products, whereas those who purchased imported milk powder increased from $34 \%$ to $47 \%$ in China due to milk adulterating by melamine as Qian et al. (2011) ${ }^{[57]}$.

\section{Impacts on farmers/producers}

Adulteration not only has an effect on big enterprises but also farmers or producers (like dairy, honey, coffee, wheat, etc) can be affected by the weakest link in the industry chain. Many farmers suffered massive losses, cost increases due to feed costs, milk cow shortage caused by mass sales or slaughter during the crisis, for example in the case of China dairy Scandal and lack of acceptance of the products (Qian et al., 2011 and Nie, 2008) ${ }^{[57,51] .}$

\section{Impacts on consumers}

Human health is highly sensitive to food adulteration. Hazardous effects of food adulteration is associate with diarrhea, abdominal pain, nausea, vomiting, eyesight problem, headache, cancer, anemia, insomnia, muscular paralysis and brain damage, stomach disorder giddiness, joint pain, liver 
disorder, dropsy, gastrointestinal problems, respiratory distress, edema, cardiac arrest, glaucoma carcinogenic effects, kidney failure, digestive system disorders, etc as reported by Anita and Neetu (2013) ${ }^{[4]}$, Faraz et al. (2013) ${ }^{[23]}$ and Lakshmi et al. (2012) ${ }^{[38]}$. It is found that there are various chemicals and colors used in fruits and vegetables which are very poisonous for health. Calcium carbide used in mangoes, bananas, copper sulphate used to ripen fruits faster, oxytocin a hormone used for faster growth of pumpkin, watermelon, brinjal, gourds, cucumber. Wax adds shine on apples and pears. Cheap green colors containing chemicals such as metallic lead applied to bitter gourd and leafy vegetables to give fresh color. Pesticides \& herbicides used excessively for growing fruits and vegetables. Consumption of chemicalladen fruits and vegetables can prove disastrous for digestive system, eyes and liver (Lanzhou, 2008) ${ }^{[39]}$. It can also results in vomiting and diarrhea in children, kidney failure. Oxytocin can lead to damage of the brain (Anita and Neetu, 2013) ${ }^{[4]}$. The individuals are unfortunate victims of this adulteration trade running in full swing and uncurbed.

In 1988, 600 persons in Kolkata (West Bengal) suffered from paralysis in hands after having consumed the rapeseed oil adulterated with tricresyl phosphate which is generally used in varnishes and hydraulic fluid. Adulteration of mustard oil with Mexican prickly poppy/argemone (Argemone mexicana) oil caused dropsy in Delhi in 1998, Gwalior (Madhya Pradesh) in 2000, and Kannauj and Lucknow (Uttar Pradesh) in 2002 and 2005 respectively. Various clinical symptoms were obvious and in severe cases, death occurred due to cardiac and respiratory failure (FSSA, 2011) ${ }^{[24]}$. Lately, the Food and Safety Standards Authority of India published the report of the national survey of adulterated foods in 33 states, viz. $8.79 \%$ incidence $(n=94,000)$ in $2008 ; 11.14 \%$ $(\mathrm{n}=113,000)$ in $2009 ; 12.65 \%(\mathrm{n}=117,000)$ in 2010 . When milk samples $(n=1791)$ collected in New Delhi were tested, $32 \%$ of them were found diluted with water, or mixed with glucose/skim milk powder $(30.6 \%)$ or harmful detergent $(5.7 \%)$. Around $44 \%$ samples of peanut oil were found adulterated with $5-20 \%$ of cotton seed oil, palm oil or castor oil consumption of which resulted in food-borne diseases and $70 \%$ of children died with diarrhea (Sudershan et al., 2009) [65]. This type of contamination comes mainly from supply chain and poor sanitary conditions in the markets where food stocks and storage structures remain unchecked and unregulated. On an average, $13 \%$ of both packaged and loose food items sold across the country have been found contaminated; and the range varied considerably from one state to another, i.e., Chandigarh (40\%), Uttarakhand (34\%), Uttar Pradesh (29\%), Rajasthan (23\%), West Bengal \& Himachal Pradesh (20\%), Bihar (17\%), Nagaland (16\%), Madhya Pradesh, Odisha \& Punjab (15\%), Tamil Nadu (14\%), Maharashtra (10\%), Karnataka (5\%) and Delhi (4\%). In another survey, $70 \%$ of milk samples did not confirm to prescribed standards; i.e., $46 \%$ were with low solid not fat due to dilution with water, and $8 \%$ were with detergents (Mishra, 2011) $)^{[44]}$

\section{Challenges of adulterations}

It is no secret that there have been significant media exposure, public health impact and decrease in consumer confidence in recent years due to some significant food safety incidents. This has increased focus on food safety by consumers, the industry, lawmakers and regulatory agencies (Ades et al., 2012) ${ }^{[1]}$. In both developed and developing countries, inadequate laws, funding and staffing appear to be common challenges to the control of substandard and counterfeited goods and services. There is also inability to prosecute offenders in developing countries as well as threats to lives of enforcement officers where gratification has not worked. In addition, there is inadequate information and technology to detect fake and adulterated products. Often times, the exact number of foreign sources of the products is not known while in terms of physical site inspection, only a negligible percentage of the facilities are covered (Dogarawa, 2013) ${ }^{[17]}$. The main challenge of food adulteration is lack of acceptance in the market due to distrusting its originality as reported by Asrat and Yilma (2014) ${ }^{[5]}$ or discouraging market (Asrat et al., 2013) for example, dairy products of Wolaita and Kucha area were recognized for its high quality thus fetch high price. Because of this, it was noted that Wolaita butter was adulterated with vegetable oil and marketed with reduced prices in Dilla and Shashemene towns (Yigrem et al., 2008) [69]. Such a practice should be avoided as it can affect among others the reputation of the butter of the area for its high quality. Therefore, there should be regulations that penalize such a criminal traders (Li, 2008a) and dishonest producers that infect different food products in various places and a more selective sample preparation and testing technology is needed to enable rapid screening of food adulteration since effective analytical techniques to detect frauds are also other challenges (Ibens, 2014) ${ }^{[32]}$.

\section{Safety measures \\ Producers and manufacturers}

At field level, for avoiding food contamination of agricultural produce, before and after harvest, there is need for a shift by adopting Good agricultural practices (GAP) including integrated pest management. Over and indiscriminate doses of synthetic fertilizers and pesticides should be replaced by need-based applications of safe and recommended pesticides. These practices would help in reducing chemical use in general and in controlling aflatoxin in particular (Kumar and Popat, 2010) [37]. Contamination of Aspergillus flavus in peanut can be controlled by Trichoderma spp. which are potent antagonists producing volatile and diffusible antibiotics (Srilakshmi et al., 2011) ${ }^{[64]}$. Other effective ecofriendly measures include spraying with a mixture of water extract $(5 \%)$ of pongam (Pongamia pinnata) bark or tamarind (Tamarindus indica) fruit (Chandra et al., 2007). Severity of fungal infection can also be lowered by spraying water extract (5\%) of leaves of neem, henna (Lawsonia inermis), or turmeric (Curcuma longa) powder (Bansal and Sobti, 1990).

In manufacturing industries, wearing of personal protective clothes, gloves and washing of whole body after working hours is the best practical remedy to avoid contact with chemicals. Moreover, safe period recommended before crop harvest is to be respected rigorously and the prescribed norms including antidotes and preventive measures have to be followed (Gahukar, 2011). In industrial areas, dumping of poisonous effluents needs to be avoided. Other preventive measures include strict control on various sources of contamination, regular follow up by authorities for recommended food standards and labelling. In case of doubt, simple chemical tests can confirm the content of contaminants (FAO, 2011) [21]. To safeguard consumers, locally and globally, from residues of chemicals, the MRL has been fixed for each crop or food product by Codex Alimentarius Commission (CAC) which is an apex body of FAO and WHO. 


\section{Consumers}

Prevention of admixture is possible while purchasing food, by adopting simple means at household level and by reporting to concerned authorities. It is better to check the quality of food grains at the time of purchase and only branded and ISI marked products should be preferred. One should reject artificially colored rice, pulses, sweets, spices, junk food, adulterated milk or oil. The fruits which are just slightly under-ripe and not over-ripe should be purchased to stagger the ripeness. At home, whole grains (cereals and pulses), spices and condiments can be sorted out manually from admixture. Otherwise, grains can be sieved and foreign materials including sand, pebbles or dirt particles can be easily discarded. In fact, this is an age-old household practice followed by rural people in India. In case of fruits, peeling can remove wax coating containing toxic material. Moldy grains may contain fumonisin toxin-B1 produced by Fusarium moniliforme or F. verticilliodes. These grains should not only be separated and discarded but also properly destroyed. Parboiling of grass pea grains and washing with fresh water is helpful in removing $>90 \%$ of toxin (Beta-noxalyl amino alanine, BOAA) (Gahukar, 2009) ${ }^{[27]}$. Food grains and nuts should be dried immediately after crop harvest and stored in clean, dry and cool place to prevent mold development. The grains showing caking during storage may be dried again. Irrespective of this measure, whenever the mold growth is noticed, never scrape it off and eat the remaining grains. Instead, these grains must be burnt or buried and not simply discarded. Cleaning for extraneous matter, insect damaged and visible moldy grains can reduce the level of contamination during handling of raw material. Washing of grains four times with gentle rubbing of grains and drawing water after each wash followed by cooking can remove $>95 \%$ of residues of malathion, methyl parathion, fenvalerate, cypermethrin or chlorpyriphos (Nair and Mathew, 2013) ${ }^{[48]}$. Thus, processing (washing, drying and milling) and cooking can help to prevent incidental poisoning.

Consumers should purchase canned foods after verifying expiry date and never purchase exposed foods, ice and juice sold in open market that are often suspected to be contaminated. Containers should be washed with soap and hot water before pouring juice or transferring food. In case of doubt, infection of coliform bacteria on fruits and vegetables can effectively be controlled with plant extracts in water (Negi, 2012) ${ }^{[50]}$ or petroleum ether (2 ug ml-1) of moringa (Moringa oleifera) leaves (Rahman et al., 2010) ${ }^{[58]}$. Similarly, fruits and vegetables should be washed properly or peeled them off to remove the chemical contaminants deposited on them. Pesticide residues are adsorbed or deposited in waxy layer of the soft fruits and vegetables, those with high fat content should therefore be avoided. Washing vegetables and fruits in $2 \%$ salt solution for 10 minutes followed by rinsing 2-3 times in cold water can get rid of much of toxins. It has been ascertained that the cooked food is safer than the raw food as cooking process reduces the residual amount of contaminants by degradation and detoxification (Gahukar, 1999) ${ }^{[28]}$. However, cooked food stored for several hours in the open space or refrigerated for a long time can favour bacterial growth because depending upon type of food, refrigeration generally inhibits mold growth but does not deter it completely. It is therefore wise to reheat the stuff before serving. For this purpose, improved cooking methods would prove advantageous; for example, cooking for a long time or at high temperature destroys bacteria and reduces aflatoxin content; cutting meat into small pieces ensures thorough penetration of heat. Boiling milk at high temperature or heating oil up to a particular flash point can degrade/detoxify the persistent pesticide residues (Gahukar, 2009) ${ }^{[25]}$.

Consumers and social organizations should send samples of vegetables, fruits; food grains etc. to local testing laboratories and lodge the complaint with local municipality or civil authorities. The action taken against defaulters would provoke others to fight against adulteration and contamination. In tribal areas, food provided in school and college canteens by the All India Food Processors Association and other agencies was not up to standard and was often rejected by children. In such cases, the consumer education programs play an important role in imparting knowledge on the purchase and use of safe foods. Likewise, strong enforcement mechanisms, effectiveness of civil society groups and close liaison between local and state bodies can facilitate the follow-up of the uniform implementation of the food laws. For this, vibrant consumer movement at national level particularly by senior citizens, ladies clubs and NGOs can result in some progress.

\section{Role of government agencies Market surveys}

Market surveys of the dangerous build-up of toxins in food help prevent incidental poisoning. The health authorities can keep watch on illegal activity pertaining to ethylene or oxytocin in vegetables and fruits, and dyes or acids in edible oil. It is mandatory to declare the colour on the label of container. Therefore, admixtures of various colors should be checked regularly by market surveys and sampling by the Public health inspectors. For the animal feeds with additives (diethyl silbestrol, nitrites, nitrates, antibiotics) sold, competent authorities can execute current regulations. However, metal detection is certainly difficult by illiterate consumers. Therefore, sampling and verification of content should only be done by competent authority and samples sent to the recommended laboratory.

\section{Inspection and testing}

The existing food chain is complex, adaptive and efficient but the infrastructure connecting various stakeholders is rather weak and scattered. As such, there are only a few real channel masters who can manage the supply-demand situation, coordinate whole supply chain and supervise logistic activities. Regular food sampling and testing at the retail level can ensure that shops store only safe foods and remove from the shop-selves other foods seemed unfit for consumption. The reality is that the demand forecasting is nearly nonexisting and farmers try to push into market what they produce. Recently, cold chain has been introduced in the food supply system to maintain ideal storage conditions for perishables from the point of origin to the point of human consumption. A well-organized cold chain can therefore reduce spoilage, can retain the quality of the harvested produce and can guarantee a cost- efficient delivery to the consumer with adequate attention to the customer services. Along with cold chain, the supply chain is required to be designed and built in an integrated manner using the processes of product development, and efficient procurement supported with adequate information technology and software packages.

Food safety measures are of utmost importance to food producers, retailers, public authorities and health inspectors. Nowadays, food safety programs are focusing on a "farm to table/farm to fork" approach as an effective means of reducing food-borne diseases. Thus, the data on integration, 
financial flow management, supply-demand matching, collaborative forecasting, information-sharing and food movement synchronization in supply chain are needed to facilitate current food control. Recently, Lala Lajpat Rai University of Veterinary and Animal Sciences, Hisar (Haryana) developed a kit for rapid spot testing to detect urea in milk. The irradiation of foods and food products as postharvest treatment can be combined with regulatory measures at both national and international levels to prevent contamination and make the food safe. The National Monitoring Agency vested with powers decides policy issues on food irradiation and has the responsibility of regular surveillance and monitoring for food safety. The Hazard analysis critical control point (HACCP) system has now been introduced to identify, evaluate and control hazards arising from crop harvest until the point of consumption. Recently, Luo et al. (2012) ${ }^{[42]}$ recommended application of a loopmediated isothermal amplification assay for rapid identification of aflatoxin-producing molds. Likewise, two multiplex polymerase chain reaction assays has been effective to detect genes of five types of $E$. coli (Hegde et al., 2012) ${ }^{[30]}$. On the contrary, the traditional quality control system was relying mostly on end-food hygiene-HACCP system with guidelines for application as ISO-15000 in 1998. In addition to four central laboratories, state governments and municipal councils/corporations in cities have their own laboratories to handle the food adulteration and contamination. In future, checking for quality marks such as ISI, Food Products Order (FPO/AGMARK), and follow up of labeling directions should be a regular practice. In reality, it is difficult to monitor quality of the processed foods in small cottages or household manufacturing/processing units in rural areas where strict adherence to the rules and regulations is always needed. Therefore, the Food Inspectors and Public Food Analysts are authorized for launching prosecution.

\section{Regulation and certification}

Food adulteration is often linked with impurities in the food grains sold through the Public distribution system (PDS), the only food supply agency under central government. Proper enforcement of the regulations is lacking and most state governments do not have the machinery to conduct checks from time to time. Likewise, spoilage, sanitation and contamination of food have not been given requisite attention by health authorities. Therefore, concept of the Food safety objective developed by FAO and WHO should be introduced and form an integral part of food chain management (Barro et al., 2007) ${ }^{[9]}$.

The inspection and certification are done by the Bureau of Indian Standards (BIS) under the Directorate of Marketing and Inspection (DMI). The BIS operates the ISI (Certification marks) Act of 1952 which had laid down the quality standards for processed foods supported by testing methods for almost all consumer goods. The ISI certification though voluntary, becomes mandatory under certain acts. The AGMARK standard has been revised by the DMI and the Agriculture Produce Act has been introduced under which the government fixes the quality specifications. The Central Committee for Food Standards is the primary policy making body which advises government on application of specifications, quality control inspection and testing whereas the Food Safety and Standards Authority of India is an autonomous statutory authority under administrative control of the Ministry of Health and Family Welfare. It regulates the manufacturing, storage, distribution, sale and import, and thereby, insures availability of safe food for human consumption. Recently, formation of the National Food Quality Control Board has also been suggested by the government. Also, Ministry of Health and Family Welfare has constituted a National Codex Committee, and has established the National Food Science and Risk Assessment Centre for carrying out analysis of food surveillance data recorded from laboratories in order to generate data on food hazards and outbreaks of food borne diseases and to implement the codex-adopted general principles of food hygiene and recent guidelines for hazard analysis. These data would be helpful in prevention, intervention and control of at least major cases. For detecting contamination of the food-borne diseases caused by microorganisms, modern laboratory facilities with pollution control measures, food quality inspection, and monitoring and management (including treatment, packaging and preservation) are needed. For facilitating this program, the central government recently planned to set-up cluster laboratories of accredited standards for every 4-5 districts to carry out basic tests and zonal food laboratories ( 1 for 10 districts) to perform tests for residues and heavy metals and 10 referral laboratories for reference (Gahukar, 2014) ${ }^{[26]}$.

The export of Indian foods to the Middle-East, Europe, Australia and the USA is on increase. In some consignments, foods are rejected due to sub-standard supply. Thus, there is need to revamp food supply chain and regulatory agencies such as, Agricultural and Processed Food Products Export Development Authority. On legal front, Indian government established certain laws and rules for prevention of food adulteration and contamination in food service establishments and the amendments are regularly published in gazettes by the Food and Drug Administration concerning Prevention of Food Adulteration Act 1954 (8th amendment in 2008); Prevention of Food Adulteration Rules 1955 (1st amendment in 2011); Export (Quality Control and Inspection) Act 1963; Indian Consumers Protection Act 1968; The Insecticides Act 1968; Meat Food Products Order 1973; Hazardous Chemicals Rules 1989; Milk and Milk Products Order 1992; Fruit Products Order 1995; Food Safety and Standards Act 2006; Food Safety and Standards Authority of India 2008; Food Safety and Standards rules 2011. Further, the Consumer Protection Act makes the public aware of food contamination and prevention of fatal incidents. Also, Consumers Association of India and Consumers Education and Consumers Guidance Society of India collaborate actively with government and voluntary organizations. In addition to this national network, international support is sought through WHO/FAO International Food Safety Authorities Network, Codex Committee on Food Additives and Codex Committee on Contaminants in Food.

It is generally expected that the guidelines of the management systems are in the compliance with HACCP. In future, international co-operation, information-sharing mechanism, dialogue between stakeholders, involvement of private sector, labeling and tracking systems for traceability, all can strengthen the existing rules and regulations. India being a signatory to the World Trade Organization, it becomes a party to the related agreements which lay emphasis on the CAC decisions. The CAC adopted general principles of food hygiene as an international code of practice. Likewise, the WHO's Food Contamination Monitoring and Assessment Program has encouraged developing countries to undertake total diet studies as a matter of public health significance. For example, the enterprise resource planning is designed to track products in lots during food processing for admixture of 
additional ingredients, portioning and transformation. Imparting training to food handlers including kitchen staff in basic hygienic practices will facilitate garbage disposal and strengthen official control over the quality and safety of foods served on streets and in open-air food stalls (De, 2010) ${ }^{[12]}$.
Recently, Lin. (2011) ${ }^{[41]}$ examined regulatory systems and described difficulties that international organizations encounter and has advocated reforms to improve the international governance strategy of food safety.

Table 2: Different food articles and adulterant detection techniques for them

\begin{tabular}{|c|c|c|c|c|c|}
\hline \multirow{2}{*}{$\begin{array}{c}\text { Food } \\
\text { Article }\end{array}$} & \multirow{2}{*}{ Adulterant } & \multicolumn{3}{|c|}{ Methods of adulterant detection } & \multirow{2}{*}{ References } \\
\hline & & Physical & Biochemical & Molecular & \\
\hline $\begin{array}{l}\text { Black } \\
\text { pepper }\end{array}$ & Papaya seeds & $\begin{array}{c}\text { Papaya seeds can be separated out from pepper } \\
\text { as they are shrunken, oval in shape and greenish } \\
\text { brown or brownish black in colour }\end{array}$ & $\begin{array}{l}\text { Near infrared hyper spectral } \\
\text { imaging (NIR HSI) Mid- } \\
\text { infrared spectroscopy(MIR) }\end{array}$ & SCAR & $\begin{array}{l}\text { Dhanya et al., } \\
\quad 2009^{[14]}\end{array}$ \\
\hline $\begin{array}{c}\text { Mustard } \\
\text { seed and } \\
\text { oil }\end{array}$ & $\begin{array}{l}\text { Argemone } \\
\text { seeds/ oil } \\
\text { (Argemone } \\
\text { mexicana), rape } \\
\text { seed, ragi }\end{array}$ & $\begin{array}{c}\text { Mustard seeds have a smooth surface. The } \\
\text { argemone seed have grainy and rough surface } \\
\text { and are black and hence can be separated out by } \\
\text { close examination. When Mustard seed is } \\
\text { pressed inside it is yellow while for argemone } \\
\text { seed it is white }\end{array}$ & TLC, HP-TLC & $\begin{array}{c}\text { Real time- } \\
\text { PCR }\end{array}$ & $\begin{array}{l}\text { Shelar et al., } \\
2011^{[61]} \\
\text { Mustorp et al., } \\
2008^{[47]}\end{array}$ \\
\hline $\begin{array}{l}\text { Turmeric } \\
\text { powder }\end{array}$ & $\begin{array}{l}\text { Coloured } \\
\text { saw dust, } \\
\text { metanil } \\
\text { yellow }\end{array}$ & $\begin{array}{c}\text { When few drops of concentrated hydrochloric } \\
\text { acid are added in a spoonful of turmeric powder } \\
\text { in test tube, instant appearance of pink colour } \\
\text { which disappears on dilution with water shows } \\
\text { the presence of turmeric. If the colour persists, } \\
\text { metanil yellow is present }\end{array}$ & TLC, HPLC & RAPD & $\begin{array}{l}\text { Sasikumar et al., } \\
\quad 2005^{[60]}\end{array}$ \\
\hline Cinnamon & $\begin{array}{c}\text { Cassia ; aromatized and } \\
\text { powdered beechnut } \\
\text { husk; hazel nut;almond } \\
\text { shell dust }\end{array}$ & - & - & $\begin{array}{c}\text { Sequencin } \\
\text { g; SSCP }\end{array}$ & $\begin{array}{l}\text { Kojoma, et al., } \\
2002 \text { [35] }\end{array}$ \\
\hline Coffee & Chicory & $\begin{array}{c}\text { Gently sprinkle the coffee powder sample on the } \\
\text { surface of water in a glass. The coffee floats } \\
\text { over the water but chicory begins to sink down } \\
\text { within a few seconds. } \\
\text { The falling chicory powder particles leave } \\
\text { behind them a trail of colour, due to large } \\
\text { amount of caramel. }\end{array}$ & $\begin{array}{c}\text { MIR } \\
\text { spectroscopy }\end{array}$ & $\begin{array}{c}\text { Real-time } \\
\text { PCR }\end{array}$ & $\begin{array}{l}\text { Patrizia et al., } \\
\quad 2010^{[55]}\end{array}$ \\
\hline Tea & $\begin{array}{l}\text { Iron flakes, Cashew } \\
\text { husk, Leather } \\
\text { flakes }\end{array}$ & $\begin{array}{c}\begin{array}{c}\text { Spread a small quantity of sample on a piece of } \\
\text { paper, draw a magnet over it. Iron flakes cling to } \\
\text { the magnet. } \\
\text { Prepare a paper ball. Fire the ball and drop a } \\
\text { little amount of sample on it. The presence of } \\
\text { leather flakes emits an odour of burnt leather. }\end{array}\end{array}$ & GC-MS & $\begin{array}{l}\text { Species } \\
\text { Specific } \\
\text { PCR } \\
\text { ITS of } 5 S \\
\text { rRNA }\end{array}$ & $\begin{array}{l}\text { Dhiman and } \\
\text { Singh, 2003 } \\
\text { Bandana and } \\
\text { Mahipal, 2003 }\end{array}$ \\
\hline Oats & $\begin{array}{c}\text { Wheat } \\
\text { contamination }\end{array}$ & 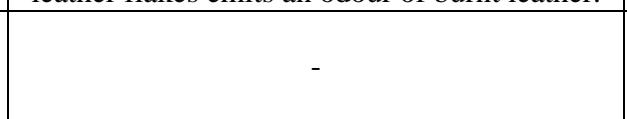 & - & $\begin{array}{l}\text { Species } \\
\text { specific } \\
\text { PCR }\end{array}$ & $\begin{array}{l}\text { Koppel et al., } \\
\quad 1998^{[36]}\end{array}$ \\
\hline Olive oil & $\begin{array}{l}\text { Less expensive } \\
\text { oils }\end{array}$ & $\begin{array}{c}\text { Detection of origin } \\
\text { and authenticity } \\
\text { verification of virgin olive oil }\end{array}$ & $\begin{array}{c}\text { MIR } \\
\text { spectroscopy }\end{array}$ & $\begin{array}{l}\text { SCAR } \\
\text { AFLP/ } \\
\text { RAPD }\end{array}$ & $\begin{array}{l}\text { Pafundo et al., } \\
\quad 2007^{[52]}\end{array}$ \\
\hline Milk & $\begin{array}{l}\text { Water, } \\
\text { Urea, } \\
\text { Iron and } \\
\text { zinc }\end{array}$ & $\begin{array}{l}\text { The milk can easily be tested by urease strips, } \\
\text { also milk does not contain glucose or invert } \\
\text { sugar, if test for glucose with urease strip found } \\
\text { positive, it means milk is adulterated }\end{array}$ & $\begin{array}{c}\text { ELISA, Fourier } \\
\text { transform } \\
\text { infrared spectroscopy } \\
\text { and multivariate } \\
\text { analysis, Pulsed field gel } \\
\text { electrophoresis, MIR and } \\
\text { NIR }\end{array}$ & $\begin{array}{l}\text { PCR based } \\
\text { method, } \\
\text { ribotyping, } \\
\text { Real time } \\
\text { PCR }\end{array}$ & Hurley et al., 2004 \\
\hline Meat & $\begin{array}{l}\text { Metal, glass stones, } \\
\text { bones }\end{array}$ & _ & ELISA & PCR-RFLP & $\begin{array}{c}\text { Mahajan et al., } \\
2011^{[43]}\end{array}$ \\
\hline Juices & $\begin{array}{l}\text { Cheaper } \\
\text { solid } \\
\text { ingredients } \\
\text { (particularly sugars) }\end{array}$ & $\begin{array}{l}\text { The Brix test accurately determines the ratio of } \\
\text { solids to water in fruit juice. The observed ratio } \\
\text { is then compared with predetermined standards. }\end{array}$ & $\begin{array}{l}\text { Proton NMR } \\
\text { spectroscopy } \\
\text { LC-MS } \\
\text { FT-IR }\end{array}$ & - & $\begin{array}{l}\text { Vogels et al., } \\
\quad 1996[68]\end{array}$ \\
\hline
\end{tabular}

\section{Conclusion}

Adulteration in food items can cause tremendous affect on health without our knowledge. It can be prevented by few alerting steps of our society. Hike of price of food items should be checked by government. The consumer should avoid buying food from places which do not maintain proper hygiene conditions. Both local and branded food stores should be inspected by government bodies. If we tend to actively participate in these changes then we can bring about a healthy and non venturous future for the upcoming generations.

\section{References}

1. Ades G, Henry CW, Feldstein F. The Food Safety Challenge of the Global Food Supply Chain. WEBINARS, Food safety magazine, 2012. 
2. Afzal A, Mahmood MS, Hussain L, Akhtar, Masood. Adulteration and Microbiological Quality of Milk (A Review). Pak J Nutrit. 2011; 10(12):1195.

3. Alauddin S. Food adulteration and society. Global research analysis International. 2012; 1(7):3-5.

4. Anita G, Neetu S. Hazards of new technologies in promoting food adulterateon. J EnvSci, Tox. F Sci. 2013; 5(1):08-10.

5. Asrat A, Zelalem Y. Patterns of milk and milk products adulteration in Boditti town and its surrounding, South Ethiopia. Scholarly J Agric. Sci. 2014; 4(10):512-516.

6. Asrat A, Zelalem Y, Ajebu N. Quality of fresh whole milk produced in and around Boditti, Wolaita, South Ethiopia. Afri. J Anim. Biomed. Sci. 2012; 7(2):95-99.

7. Awan Adeela, Naseer Misbah, Aasfa Ali, Muhammad Rehana, Furhan. A study on chemical composition and detection of chemical adulteration in tetra pack milk samples commercially available in Multan. Pak. J Pharma. Scie. 2014; 27(1):183.

8. Awasthi S, Jain K, Das A, Alam R, Surti G, Kishan N. Analysis of Food quality and Food Adulterants from Different Departmental \& Local Grocery Stores by Qualitative Analysis for Food Safety. IOSRJESTFT. 2014; 8(2):22-26.

9. Barro N, Bellow AR, Itsteimbou Y, Savadogo A, Ouattara CAT, Nikiema AP et al. Street-vended foods improvement- contamination mechanisms and application of food safety objective strategy: Critical review. Pakistan Journal of Nutrition. 2007; 6:1-10.

10. Chanda T, Debnath GK, Hossain ME, Islam MA, Begum MK. Adulteration of raw milk in the rural areas of Barisal district of Bangladesh. Bangladesh Journal of Animal Sciences. 2012; 41(2):112-115.

11. Cofie CA. The Impact of Illicit Trade and Counterfeit Goods on National Development, 27th June, 2012.

12. De S. Food safety: Steps of rising concern. Everyman's Science. 2010; 65:219-222.

13. Dehinenet G, Mekonnen H, Ashenafi A, Emmanuelle G. Determinants of raw milk quality under a smallholder production system in selected areas of Amhara and Oromia National Regional States. Ethiopia. Agric. Biol. J N. Am. 2013; 4(1):84-90.

14. Dhanya K, Syamkumar S, Sasikumar B. Development and application of SCAR marker for the detection of papaya seed adulteration in traded black pepper powder. Food Biotechnology. 2009; 23:97-106.

15. Dhanya K, Syamkumar S, Sasikumar B. Development and application of SCAR marker for the detection of papaya seed adulteration in traded black pepper powder. Food Biotechnology. 2009; 23:97-106.

16. Dhiman B, Singh M. Molecular detection of cashew husk (Anacardium occidentale) adulteration in market samples of dry tea (Camellia sinensis). Planta Medica. 2003; 69(9): 882-884.

17. Dogarawa LB. Overview of the Socio-economic Implications and Management of Product Faking and Adulteration. Greener Journal of Business \&Management Studies. 2013; 3(3):119-131.

18. Ehsan M, Rahman M, Saadi H. Effect of Fuel Adulteration on Engine Crankcase Dilution. Journal of Mechanical Engineering. 2010; 41(2).

19. El-Loly MM, Mansour AIA, Ramadan RO. Evaluation of Raw Milk for Common Commercial Additives and Heat Treatments. International Journal of Food Safety. 2013; 15:7-10.
20. ESA. ES ISO. Milk powder- Determination of soy and pea proteins using capillary electrophoresis in the presence of sodium dodecyl sulfate (SDS-CE)-Screening method, 2012.

21. FAO. Assuring Food Safety and Quality: Considerations of Food Safety and Consumer Protection. FAO Corporate Document Repository, Agriculture and Consumer Protection Division, Food and Agriculture Organization, Rome, Italy, 2011.

22. FAO/WHO. Joint FAO/WHO food standards programme FAO/WHO coordinating committee for Africa, seventeenth session, Rabat, morocco, 2007, 23-26.

23. Faraz Lateef AM, Mustafa MI, Akhtar P, Yaqoob M, Rehman S. Detection of adulteration, chemical composition and hygienic Status of milk supplied to various canteens of educational Institutes and public places in Faisalabad. Journal of Animal and Plant Sciences. 2013; 23(1):22-26.

24. FSSA. Food Safety and Standards Authority of India, Ministry of Health and Family Welfare, Government of India, New Delhi, India, 2011.

25. Gahukar RT. Adulterated food. Kisan World. 2009; 36(8):33.

26. Gahukar RT. Food adulteration and contamination in India: occurrence, implication and safety measures. International Journal of Basic and Applied Sciences. 2014; 3(1):47-54.

27. Gahukar RT. Adulterated food. Kisan World. 2009; 36(8):33.

28. Gahukar RT. Agro-medical Guide of Synthetic Pesticides, 1st edn., Agri-Horticultural Publishing House, Nagpur, India, 1999.

29. Hamburg MA. Food and Drug Partnership for Safe Medicines Interchange, 2010.

http://www.fda.gov/downloads/Drugs/ResourcesForYou/ Consumers/BuyingUsingMedicineSafely/Cou nterfeitMedicine/UCM235240.pdf.

30. Hegde A, Ballal M, Shenoy S. Detection of diarrheogenic Escherichia coli by multiplex PCR. Indian Journal of Medical Microbiology. 2012; 30:279-284.

31. Hurley IP, Ireland HE, Robert CC, Williams JHH. Application of immunological methods for the detection of species adulteration in dairy products. International Journal of Food Science \& Technology. 2004; 39(8):873878.

32. Ibens D. The great melamine scare. The scandal draws attention to standards and leads to development of new tests. Food Quality \& Safety, Current Issue, 2014.

33. Kannan K, Tanabe S, Gisey JP, Tasukawa R. Organochlorine pesticides and polychlorinated biphenyls in foodstuffs from Asian and Oceanic countries. Rev. Environ. Contamin. Toxicology. 1997; 152:1-55.

34. Khan MTG, Zinnah MA, Siddique MP, Rashid MHA, Islam, Choudhury KA. Physical and Microbial Qualities of Raw Milk Collected from Bangladesh Agricultural University Dairy Farm and the Surrounding Villages, Bangladesh Agricultural University, Mymensingh-2202, Bangladesh, Bangl. J Vet. Med. 2008; 6:217-221.

35. Kojoma M, Kurihara K, Yamada K, Sekita S, Satake M, Iida O. Genetic identification of cinnamon (Cinnamomum spp.) based on the trnL-trnF chloroplast DNA. Planta Medica. 2002; 68:94-96.

36. Koppel E, Stadler M, Luthy J, Hubner P. Detection of wheat contamination in oats by polymerase chain reaction (PCR) and enzyme-linked immunosorbent assay 
(ELISA). European Food Res. and Tech. 1998; 206:399403.

37. Kumar GDS, Popat MN. Farmers' perceptions, knowledge and management of aflatoxins in groundnuts (Arachis hypogaea L.) in India. Crop Protection. 2010; 29:1534-1541.

38. Lakshmi V. Review article on food adulteration. International J of Sci. Inventions Toady. 2012; 1(2):106113.

39. Lanzhou D. $80 \%$ of consumers were affected by the milk scandal - survey made by Lanzhou Investigation Team of Statistics Bureau, 2008.

40. Li SL, Cao ZJ, Zhang YG, Yang DQ, Zhou XY. How to regulate the dairy industry in China? Chin J Animal Sci. 2008; 18:44-50.

41. Lin CF. Global food security: Exploring key elements for an international regulatory strategy. Virginia Journal of International Law Association. 2011; 51:637-694.

42. Luo J, Vogel PF, Niessen L. Development and application of a loop-mediated isothermal amplification assay for rapid identification of aflatoxigenic molds and their detection in food samples. International Journal of Food Microbiology. 2012; 159:214-224.

43. Mahajan MV, Gadekar YP, Dighe VD, Kokane RD, Bannalikar AS. 2011.

44. Mishra SS. Pesticide-rich food. Down To Earth. 2011; 19(18):16.

45. Mishra SS. Pesticide-rich food. Down To Earth. 2011; 19(18): 16.

46. Molecular detection of meat animal species targeting MT 12S rRNA gene. Meat Sci., 88(1):23-27.

47. Mustorp S, Axelsson CE, Svensson U, Holck A. Detection of celery (Apium graveolens), mustard (Sinapis alba, Brassica juncea, Brassica nigra) and sesame (Sesamum indicum) in food by real-time PCR. European Food Research and Technology. 2008; 226:771-778.

48. Nair KP, Mathew TB. Home processing to address food safety issues in cereals. Journal of Insect Science. 2013; 26:111-119.

49. Narayan D. Food Adulteration: Types, worldwide laws and futures. Health care, 2014.

http://www.biotecharticles.com/Healthcare-Article/FoodAdulteration-Types-Worldwide-LawsFuture-3165.html.

50. Negi PS. Plant extracts for the control of bacterial growth: Efficacy, stability and safety issues for food application. International Journal of Food Microbiology. 2012; 156:7-17.

51. Nie YL. Collections of speeches in the Summit Forum of dairy industry development in China. China Dairy. 2008; 12:10-19.

52. Pafundo S, Agrimonti C, Maestri E, Marmiroli N. Applicability of SCAR markers to food genomics: olive oil traceability. J Agric. and Food Chem. 2007; 55:60526059.

53. Pandit GG, Sharma S, Srivastava PK, Sahu SK. Persistent organochlorine pesticide residues in milk and dairy products in India. Food Additives and Contaminants. 2002; 19(2):153-157.

54. Pandpal SD, Sirvastava AK, Negi KS. Estimation of quality of raw milk (opened and branded) by milk adulteration testing kit. Ind. J Commu. Health. 2012; 24(3):188.

55. Patrizia T, Furlan M, Pallavicini A, Giorgio GN, Vignes Lebbe R. Coffee species and varietal identification. In:
Tools for Identifying Biodiversity: Progress and Problems, 2010, 307-313.

56. Pilizota V, Nedic NT. Advances in Honey Adulteration Detection. Food safety Magazine, The online marketplace for food safety solutions, 2009. http://www.foodsafetymagazine.com/magazinearchive1/a ugustseptember-2009/advances-in-honey-adulterationdetection/.

57. Qian G, Guo X, Guo J, Wu J. China's dairy crisis: impacts, causes and policy implications for a sustainable dairy industry. IJSDWE. 2011; 18(5):434-441.

58. Rahman MM, Akhter S, Jamal M, Pandeya DR, Haque MA, Alam MF. Control of coliform bacteria detected from diarrhea associated patients by extracts of Moringa oleifera. Nepal Medical College Journal. 2010; 12(1):1219.

59. Revathi D, Sindhura A, Arvind N. Milk-borne infections. An analysis of their potential effect on the milk industry. Germs. 2012; 2(3):101-109.

60. Sasikumar B, Syamkumar S, Remya R, John Zachariah T. PCR based detection of adulteration in the market samples of turmeric powder. Food Biotechnology. 2005; 18:299-306.

61. Shelar MK, Bafna AR, Wahile AM, Suresh VT. Evaluation of edible oils for Argemone mexicana seed oil adulteration. Res. J Pharmaceutical, Biological and Chemical Sciences. 2011; 2(3):927-936.

62. Sicpa. Injury or Death from Fake Drugs, Expired Drugs, Adulterated Drugs, Mislabelled Drugs and Unauthorized Medicinal Products - NGP Pharmaceuticals; GDS Publishing, 2012.

63. Singuluri H, Sukumaran MK. Milk Adulteration in Hyderabad, India. A Comparative Study on the Levels of Different Adulterants Present in Milk. J Chroma. Separat Techniq. 2014; 5(1):212.

64. Srilakshmi P, Thakur RP, Satyaprasad K. Mechanism of biocontrol of Aspergillus flavus in groundnut by species of Trichoderma. Journal of Mycology \& Plant Pathology. 2011; 41:249-254.

65. Sudershan RV, Rao P, Polasa K. Food safety research in India: A review. Asian Journal of Food \& Agro-Industry. 2009; 2:412-433.

66. Sudershan RV, Rao P, Polasa K. Food safety research in India: A review. Asian Journal of Food \& Agro-Industry. 2009; 2:412-433.

67. Vasanthakalaam H. Studies on food handling and microbiological quality of street foods in Madurai city. Ph.D. Thesis, Dept. of Food Science and Nutrition, Agricultural and Research Institute, TNAU, 1996.

68. Vogels J, Terwel L, Tas A, Berg F, Dukel F, Greef J. Detection of adulteration in orange juices by a new screening method using Proton NMR Spectroscopy in combination with pattern recognition techniques. J Agric. Food Chem. 1996; 44(1):175-180.

69. Yigrem S, Beyene F, Tegegne A, Gebremedhin B. Dairy production, processing and marketing systems of Shashemene-Dilla area, South Ethiopia, 2008. 